\title{
Getting the dead to tell me what happened: Justice, Prosopopoeia, and Forensic Afterlives
}

\author{
THOMAS KEENAN \\ Human Rights Programme, Bard College
}

\section{Post-hoc preface}

It's not just the recovery of bones - these are stories of the most intense personal sacrifice. But the bones have meaning, too, and I'm sad to say goodbye to them when they finally go home.

- Madeleine Fullard ${ }^{1}$

It is one thing to make someone or something disappear, and another thing to make a disappearance itself disappear. The two often go hand in hand - an abduction or a murder removes someone from their world, and then the traces of that erasure are erased as well. (I say 'often' because there are exceptions: sometimes the forces of disappearance seek to amplify their power or generate obedience by promoting their capacity to make things and people go away.) In an ironic twist, though, it can also happen that projects designed to undo the first disappearance can themselves contribute to the disappearance of the disappearance. For instance, when forensic experts identify the remains of missing persons, or authorities claim that 'closure' has been brought to an otherwise unfinished chapter in history, it can seem as if the uncertainty and limbo of missing-ness has been definitively put to rest. The missing are no longer lost, but found; the lie is undone by the truth, the denial exposed.

An honest forensic practice, though, knows that nothing could be further from the truth than this truth. It's essential to tell the truth, to establish whatever fragments

\footnotetext{
A somewhat different version of this article, without the post-hoc preface, was published in a book titled Forensis: The Architecture of Public Truth (Berlin: Sternberg Press, 2014), edited by Forensic Architecture research group. The book appeared in conjunction with an exhibition of Forensic Architecture's work at the Haus der Kulturen der Welt in Berlin. The work is marked by both a profound critique of prevailing notions of forensics and a commitment to putting what we have called 'counterforensics' into play in struggles for justice, rights, and freedom. When I took part in the 'Missing and Missed' workshop, I found myself reflecting on the increasing salience and visibility of civic counter-forensic investigations. The work of the South African Missing Persons Task Team and its leader, Madeleine Fullard, featured prominently at the workshop, as did that of the Visual History and Theory Project directed by Patricia Hayes. Recent South African history has contributed enormously to the literature on how to discover and deploy evidence of all sorts - most famously, testimony, but also material evidence, documents, images, and artefacts - in the search for justice and equality after apartheid. More and more, I came to understand, the important questions concern not just what I had called the 'afterlives' of the residues of violence and oppression, especially human remains, but also the afterlives of those afterlives. Things survive, and we can learn how to read and hear what they have to say, but what happens after that? In the first section of this revised essay, and in other less obvious changes, I have tried to address some of the ways in which what I learned in South Africa, and afterwards, has made me reflect on my own thinking.

1 Quoted in J. van der Leun, 'The Odd Couple: Why an Apartheid Activist Joined Forces with a Murderer', The Guardian, 6 June 2015, https://www.theguardian.com/global/2015/jun/06/odd-couple-apartheid-activist-madeleine-fullard-convictedpoliceman-eugene-de-kock (accessed December 2018).
} 
of it can be established, and to confront the regime of disappearances with evidence of the missing - the missing persons, and the missing truths. But it is just as important to respect the fragmentary nature of what can be told, not to give in to the notion that justice, or mourning, or narration, can be concluded once and for all. Putting a body to rest, naming victims and perpetrators, telling the facts of a case, are not the end of the story - they are the beginning of the struggle to respect the very fact that people and their lives and stories went missing in the first place, and that their disappearance remains part of those stories.

South Africans have taught us many lessons about evidence, remains, and truths - and about their fragmentary status. I borrow the word 'fragment' from Nicky Rousseau's analysis of exhumations conducted by the Missing Persons Task Team (MPTT) (which took over the Truth and Reconciliation Commission's efforts to investigate missing persons and missing bodies), and its efforts to recover the bodies of some of the victims of apartheid state violence. As Rousseau points out, 'the MPTT recovered not subjects, nor even bodies, but fragments, demonstrating not recovery but its impossibility.' This incompleteness can often lead to attempts to compensate, to restore not just the missing, but their integrity, to fix their meaning and identities. It is difficult to avoid this - the demands of legal justice, of historical truth, of reparation and commemoration, and of families and communities, all tend toward this determination - but the fact of fragmentation itself should not be allowed to get lost.

Once exhumed, those fragments, as we learn from Rousseau and others, are destined for reburial, and burial is never a simple or innocent act. One never just buries a bone or a body. Human remains are always subject to a politics of comparison or analogy: bones are buried as something, as a hero, as a soldier or a guerrilla, as a member of a community or a faith or a political party. Rousseau tells a story about the burden that this, let's say, over-identification can put on families: 'The sister of a detainee who died in custody recently commented "we felt overwhelmed by the people organizing the funeral. They wanted to tell us what to say about Neil on the tombstone. My parents kept saying: But he's our son ... They said: "No he died for us."'3

Inversely, the analogies, the as-structure, can sometimes seem inadequate, and this too can lead to a sense of betrayal or mis-identification. Jay Aronson reports the dissatisfaction of one widow of an MK fighter, exhumed and then reburied without what felt like the proper ceremony: 'It was like we were burying an old person. We are not happy at all. There were no flags'. Another protested, 'we wanted these people to be buried as soldiers and respected as people who fought for this country', indicating that she felt that this identity had been insufficiently emphasised. Aronson explains that, for these relatives, 'simply finding the bones was not enough; they wished for

\footnotetext{
N. Rousseau, 'Eastern Cape Bloodlines I: Assembling the Human', Parallax, 22, 2, April 2016, 203-218, 213.

N. Rousseau, 'Identification, Politics, Disciplines: Missing Persons and Colonial Skeletons in South Africa', in É. Anstett and J.-M. Dreyfus (eds), Human Remains and Identification: Mass Violence, Genocide, and the 'Forensic Turn' (Manchester: Manchester University Press, 2015), 175-202, 191.
} 
public acknowledgment that the lives and deaths of their loved ones were integral to the struggle.' Otherwise, as one of them said, 'it was just remains. ${ }^{4}$ Perhaps filling the gaps in what is missing will always be marked by this oscillation between too much and too little; or perhaps it's simply that all efforts at making up for incompleteness will forever be haunted by just those remains.

To the initial disappearance, forensic investigators respond with stories: the remains they uncover can tell them stories, they say, of just how the person was made invisible and who he or she is. They can also challenge the subsequent disappearance: as Rousseau writes, for the TRC, exhumations provided 'material evidence of police killings and atrocity, bodies rising from their graves, as it were, to accuse members of the former government who continued to deny systematic involvement in gross human rights abuse. ${ }^{5}$ The hesitation implicit in Rousseau's use of the phrase 'as it were', highlights this second rhetorical operation: the identification of the killers and the deniers is said to come from the dead themselves, long after they have been killed. MPTT investigators speak this way in the field: 'This is a beautifully preserved hangman's fracture,' team member Kavita Chibba (Lakha) tells a reporter, while pointing to a hairline crack in Sipho Mahala's first vertebra. 'This is the second time a hangman's fracture has helped in identification' she says. And it's not only the bodies that speak and can be heard or read, but also their surroundings. As Fullard explains to the same reporter: 'you can see from the plastic lining in the graves these were pauper burials. These cheap coffins are lined with plastic.' ${ }^{3}$ The bodies - the bones and the other material remains (ruins, photographs, documents, bullet casings and tyre tracks) - seem to do the talking. Like the as-structure of reburial, this trope seems ineluctable; essential, if not entirely stable. There is no doing without it, but it too introduces an ethically vexing bind: someone has to translate this speech, but there is no final instance, no stopping point, no ultimate judge of its accuracy. Someone will be always be telling us what they hear from the dead (just as others will always be telling us how the dead should be buried), and someone else may claim to hear something different.

This tells us, in effect, that the dead are never done talking. They haunt us, and what we too easily call the 'present' - especially in times and spaces that seem far removed from the immediacy of violence. Closure is not an option. As Riedwaan Moosage writes in an exemplary analysis of 'Missing-ness, History and Apartheidera Disappearances', 'the spectre disrupts the taming of the violence and cruelty of which the "remains" are capable. More so, the spectre does not and will not allow that it be spoken for, rather it demands to be spoken of, spoken to and spoken with."

J. D. Aronson, 'The Strengths and Limitations of South Africa's Search for Apartheid-Era Missing Persons', International Journal of Transitional Justice, 5, 2, July 2011, 262-281, 278.

5 Rousseau, 'Identification', 178.

6 S. Smillie, 'Forensic Anthropologists Track Down Remains of Struggle Heroes', Business Day, 15 June 2017. Mahala, a member of the United Democratic Front, was aged just 21 when he was executed by hanging in March 1988 for participating in a necklacing in Port Elizabeth in 1985.

7 R. Moosage, 'Missing-ness, History and Apartheid-era disappearances: The Figuring of Siphiwo Mthimkulu, Tobekile "Topsy" Madaka and Sizwe Kondile as Missing Dead Persons' (PhD dissertation, Department of History, University of the Western Cape and Department of History, Vrije Universiteit Amsterdam, 2019, forthcoming), 9. 


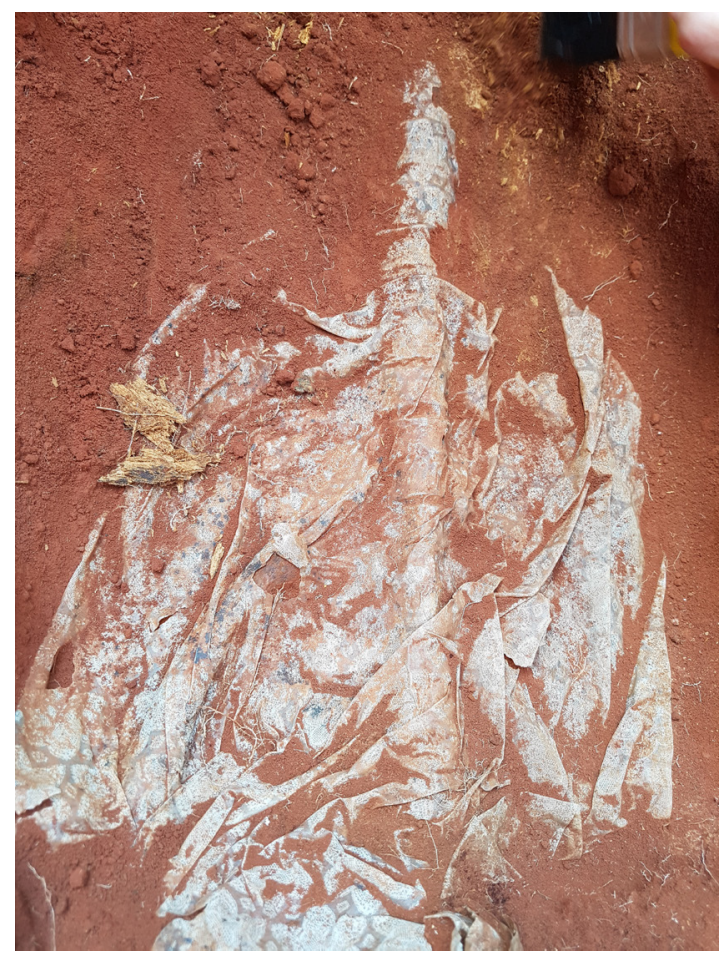

Figure 1: MPTT exhumation of executed prisoners from Mamelodi Cemetery, 2017. The wood coffin has long disintegrated, revealing the skeletal remains encased in plastic lining. Photograph by Madeleine Fullard.

Yet another politically and ethically vexing task will be to tell the difference between these prepositions.

In apartheid South Africa, life and death were marked by racial categories. This story, in particular, is not over. To this day, even the dead, as Moosage (citing Benjamin) reminds us, are not safe. This insecurity is not in itself a good or a bad thing - it is simply the spectral fact of the matter. And it can, after all, give rise to all sorts of new claims, similes, translations - and challenges. Counter-forensics can help do this. ${ }^{8}$ In this context, it can even become, as Fullard describes the MPTT, a project of 'radical anti-racism', because the dead still have more to say, because further accusations can still be made, and because there are people who have committed themselves to speaking with spectres and confronting the history of racism as an ongoing project. On this basis, as Fullard says, 'we are establishing a more egalitarian citizenry of the dead. ${ }^{9}$

December 2018

I have written about the term 'counter-forensics', which was coined by Allan Sekula, in 'Counter-Forensics and Photography', Grey Room, 55, Spring 2014, 58-77.

9 C. Parker, 'The Missing Persons Task Team: Fleshing Out the Bones of the Apartheid Era', news article posted to the Cradle of Humankind website, 20 June 2016, https://www.maropeng.co.za/news/entry/the-missing-persons-task-team-fleshing-out-thebones-of-the-apartheid-era (accessed December 2018). 


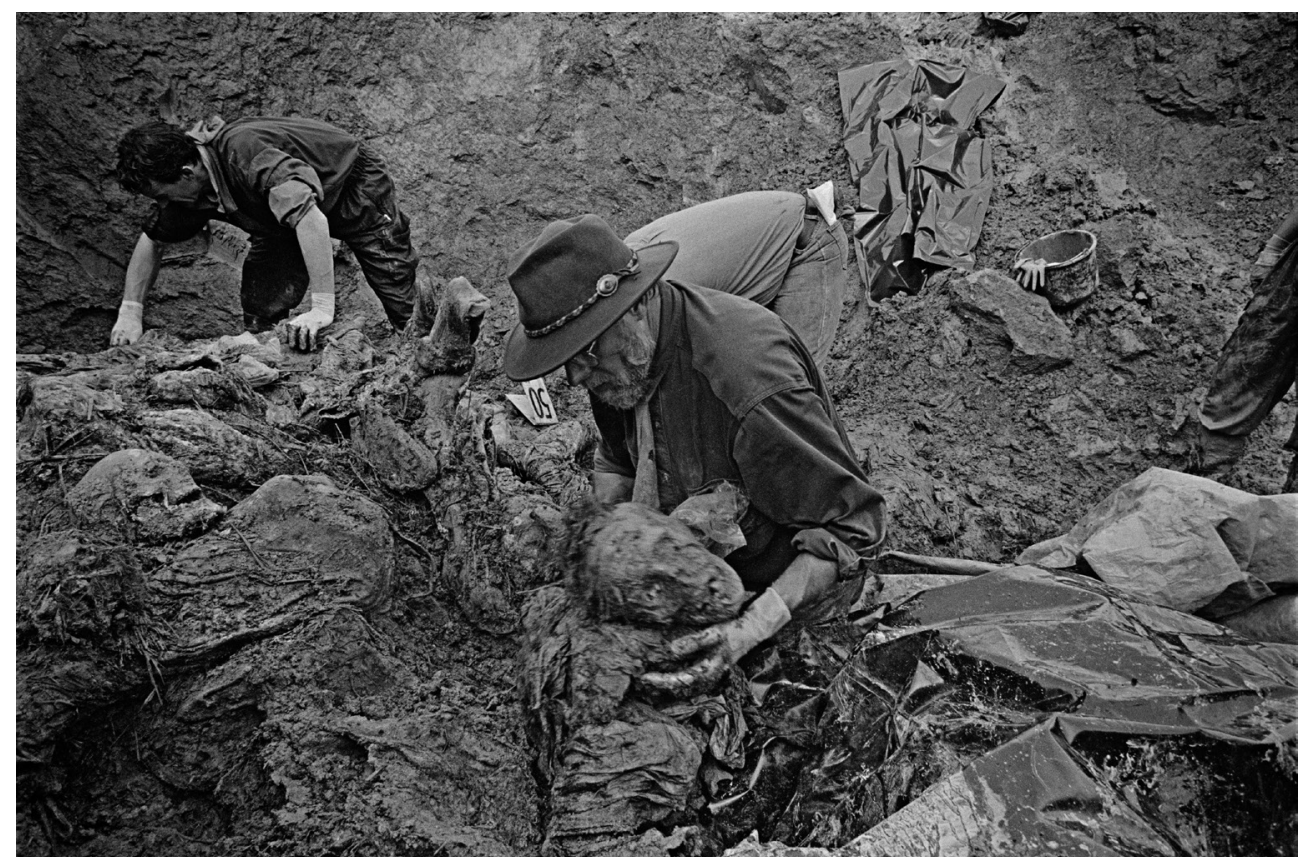

Figure 2: Forensic anthropologist William Haglund in a mass grave at the Pilica Collective Farm, near Srebrenica, Bosnia, in 1996, about which he said 'I know how to dig these graves now. I have in my own mind how the bodies should come out. I have in my own mind how it should be done. And I'm the one who has to go and testify in court.' Photograph @ Gilles Peress / Magnum Photos, used with permission.

\section{Prosopopoeia}

Almost as soon as the sun touched them, the bones started telling their stories.

- Clyde Snow ${ }^{10}$

Those who study, investigate, remember, or advocate for the missing and the missed make use of one particular rhetorical operation with surprising frequency. This would be an example:

William D. Haglund, a forensic anthropologist from Seattle, finished taking body No. 467 from the gravesite just before noon on a recent day. He zipped the remains in a plastic body bag and carried them up to tables where pathologists were reconstructing shattered skulls and severed bones.

10 Cited in R. Post, 'Clyde Snow, with Mercedes Doretti and Fredy Peccerelli: "When the Bones Speak Out", Center for Latin American Studies, University of California, Berkeley, 17 November 2000, http://clasarchive.berkeley.edu/Events/fall2000/11-1700-snow/index.html (accessed December 2018). 
He put the muddy remnants of the victim's clothing in a shopping sack and wrote the number on the outside. 'The dead are speaking to us,' he said. 'We are interpreting for the dead. The dead are telling us the same story that the living told the investigators. But this is the first time on this scale that they have been allowed to speak." ${ }^{11}$

The trope is familiar, if jarring: it is what scholars of poetry and persuasion call prosopopoeia - the attribution of a face and a voice to something inanimate. ${ }^{12}$ It recurs often in writing on forensic anthropology, including in this phrase from the pioneer of human rights forensics, Clyde Snow: 'I'm not an advocate, I'm an expert. Unless you maintain ... objectivity, you lose credibility ... and the best way is to let the bones speak for themselves.' ${ }^{13}$

Of course they can't. But they have started appearing in international courts, warcrimes trials, human rights investigations, and other public forums where they do something akin to testifying: things are speaking, without saying a word. Human rights forensics is marked by this strange oscillation between the human and the non-human, the living and the dead, and with this trope its practitioners seem to blur those very distinctions, in the name of human rights. Obviously, Snow's term, 'objectivity', is contested, but another more practical sense of the term emerges in this context: the dead, the skeletal remnants left behind when people are killed, are presented and interpreted in various forums and media, and these objects enable claims to be made, positions to be taken, justice to be pursued. The means by which this happens, however, seems enigmatically encoded in the notion of 'allowing the bones to speak. How do objects, especially human remains and ruins, become significant, start to signify, when they are identified, introduced, enlisted, and fought over as evidence in political and juridical forums?

It is this spectral status of bones that seems most interesting about forensics - in life the bones recorded something, accepted the imprint of all sorts of events, and in death, they allow for the possibility that what has been left behind can be made to signify, in another place or time.

In Mengele's Skull, the book Eyal Weizman and I wrote about 'forensic aesthetics', we explored attempts to introduce human remains as evidence in the prosecution of human rights violations. ${ }^{14}$ These attempts emerged first in Latin America in the mid1980 s, in two apparently different but structurally parallel contexts.

The first human rights forensics team in the world was constituted by a group of Argentine students in the summer of 1984 . Their formation was initiated by Snow,

11 J. C. McKinley Jr, 'From a Grave in Rwanda, Hundreds of Dead Tell Their Tale', New York Times, 16 February 1996, A4.

12 See P. de Man, The Rhetoric of Romanticism (New York: Columbia University Press, 1984), 67-81, particularly the reading of Wordsworth's phrase, 'the sun looks down upon the [grave] stone' in which de Man sees 'the speaking stone counterbalancing the seeing sun', thus linking the grave and the sun through the figure of prosopopoeia: 'The fiction of an apostrophe to an absent, deceased, or voiceless entity, which posits the possibility of the latter's reply and confers upon it the power of speech. Voice assumes mouth, eye, and finally face, a chain that is manifest in the etymology of the trope's name, prosopon poien, to confer a mask or a face (prosopon)' (75-76).

13 Quoted in National Library of Medicine, 'Visible Proofs: Forensic Views of the Body' (exhibition website), http://www.nlm.nih. gov/visibleproofs/galleries/cases/disappeared.html (accessed December 2018).

14 T. Keenan and E. Weizman, Mengele's Skull: The Advent of a Forensic Aesthetics (Berlin: Sternberg Press, 2012). 
who went there in February with a delegation of forensic scientists from the American Academy for the Advancement of Science (AAAS), at the invitation of the National Commission on the Disappeared (CONADEP). ${ }^{15}$ The dirty war in Argentina had given the world a new concept: 'the disappeared' (los desaparecidos). The following year, in an ironic inversion of the first context, state-of-the-art techniques in the forensic identification of missing persons received their most decisive test and worldwide publicity in the investigation of the body of the former Auschwitz doctor, Josef Mengele, in Brazil.

In telling the story of the emergence of forensic operations into the field of human rights, and its complex relation to the historic privilege of the witness and the document, Weizman and I were struck by the role that images played in the process - the decisive technique in Mengele's identification involved the superimposition of video images of the skull onto a photograph of the man - and by the analogy (for lack of a better word) between human remains and the structure of the photograph. Both are constituted by a complex process of imprinting, a recording of impressions, which enables or provokes an interpretive labour and the possibility of a retelling, but equally by a fundamental lack of absolute certainty, a debateability that makes them properly, or etymologically at least, forensic. (The word forensics comes from the Latin forensis, which means belonging to the forum, which is to say, the art of public persuasion and debate.) We wrote:

To the untrained eye, bones look similar - skulls are devoid of the expression and the gestures of a human face. But the bones of a skeleton are exposed to life in a similar way that photographic film is exposed to light. A life, understood as an extended set of exposures to a myriad of forces (labor, location, nutrition, violence, and so on), is projected onto a mutating, growing, and contracting negative, which is the body in life. Like a palimpsest or a photograph with multiple exposures, bones can be quite complicated to interpret. ${ }^{16}$

In other words, bones and photographs share the structure of an imprint: the moment and forces of the impression are gone forever, but they leave behind something that can be read. The sun makes its mark, and so do accidents, jobs, ancestry. The medium on which the trace is registered is not entirely neutral or passive; it has a grain and a resolution, it can record some things and not others, it can retain them for longer and shorter periods of time, it affects what it accepts. The traces can often be read and interpreted. But they are mute witnesses, and their 'language' is seldom

CONADEP was encouraged to contact the AAAS after an appeal from the Grandmothers of the Plaza de Mayo and Center for Social and Legal Studies. On the founding of the Argentine Forensic Anthropology Team (EAAF), see D. Stewart, 'Witness After Death', Sooner Magazine (Fall-Winter 1985), 4-11; M. Green, 'Dr. Clyde Snow Helps Victims of Argentina's “Dirty War" Bear Witness From the Grave', People, 8 December 1986, 111; S. G. Michaud, 'Identifying Argentina's Disappeared', New York Times Magazine, 27 December 1987, 18; C. Joyce and E. Stover, Witnesses from the Grave: The Stories Bones Tell (Boston: Little, Brown, 1991), 215-249; Argentine Forensic Anthropology Team, 'The Founding of EAAF', 2007 Annual Report (Buenos Aires, 2007$), 3$. 
- if ever - unequivocal; they need interpreters, translators, if they are persuasively to demonstrate anything. 'We are interpreting for the dead,' as Haglund said. ${ }^{17}$ Around bones and images, and their complex mix of legibility and inscrutability, grows a forum, a space of debate; they are objects in dispute, and more than one interpreter can make claims about what they say.

\section{Evidence of the obvious}

In Bury the Chains, Adam Hochschild suggests that the modern human rights campaign began with the eighteenth-century British movement to end the slave trade, and points in particular to the 1788 drawing of the slave ship Brookes made by Plymouth abolitionists and perfected by Thomas Clarkson. The drawing was straightforward and geometrical: 'a diagram, with top, side, and end views, of a fully loaded slave ship ... It gave measurements in feet and inches while showing the slaves closely lined up in rows, lying flat, bodies touching one another or the ship's hull.'18

The image was at once detailed and simple, descriptive and emotionally powerful, and it spread quickly, reproduced in 'newspapers, magazines, books, and pamphlets', ${ }^{19}$ printed as a poster, and included in Clarkson's landmark Abstract of the Evidence, delivered before the House of Commons in 1790 and 1791. Clarkson's work, says Hochschild, 'reads more like a report by a modern human rights organization than the moralizing tracts against slavery that had preceded it. ${ }^{20}$ It was a presentation of evidence, and it 'simply cited, in a crisp and businesslike way, statistics, documents, and sworn testimony. ${ }^{21}$ At its centre was the diagram of the Brookes, carefully drawn and measured, 'precise, understated, and eloquent in its starkness. ${ }^{22}$ As Hochschild says: 'Clarkson and his comrades somehow sensed that they could better evoke sympathy if they stood back and let the evidence speak for itself.'23

'Let the evidence speak for itself.' The story of the image of the Brookes, perhaps the first forensic visualisation in the history of human rights campaigns, exemplifies a recurring paradox of such projects: that what seems obvious, often isn't. 'Am I not a man and a brother?' asked another famous image of the antislavery movement, on a medallion created by the British stoneware firm, Wedgewood. ${ }^{24}$ The question's rhetorical form implies that it need not be asked, but the question can - and indeed must (that was the point) - be taken seriously. Without an affirmative answer, nothing will change. Some evidence never seems to speak for itself, or at least not loudly enough, so it has to be exposed, shown, demonstrated, stated, claimed, proven and

\footnotetext{
Quoted in McKinley, 'From a Grave in Rwanda'.

A. Hochschild, Bury the Chains (Boston and New York: Houghton Mifflin, 2005), 155

Hochschild, Bury the Chains.

Hochschild, Bury the Chains, 197.

Hochschild, Bury the Chains, 198.

Hochschild, Bury the Chains, 156.

Hochschild, Bury the Chains, 198.

Hochschild, Bury the Chains, 128.
} 


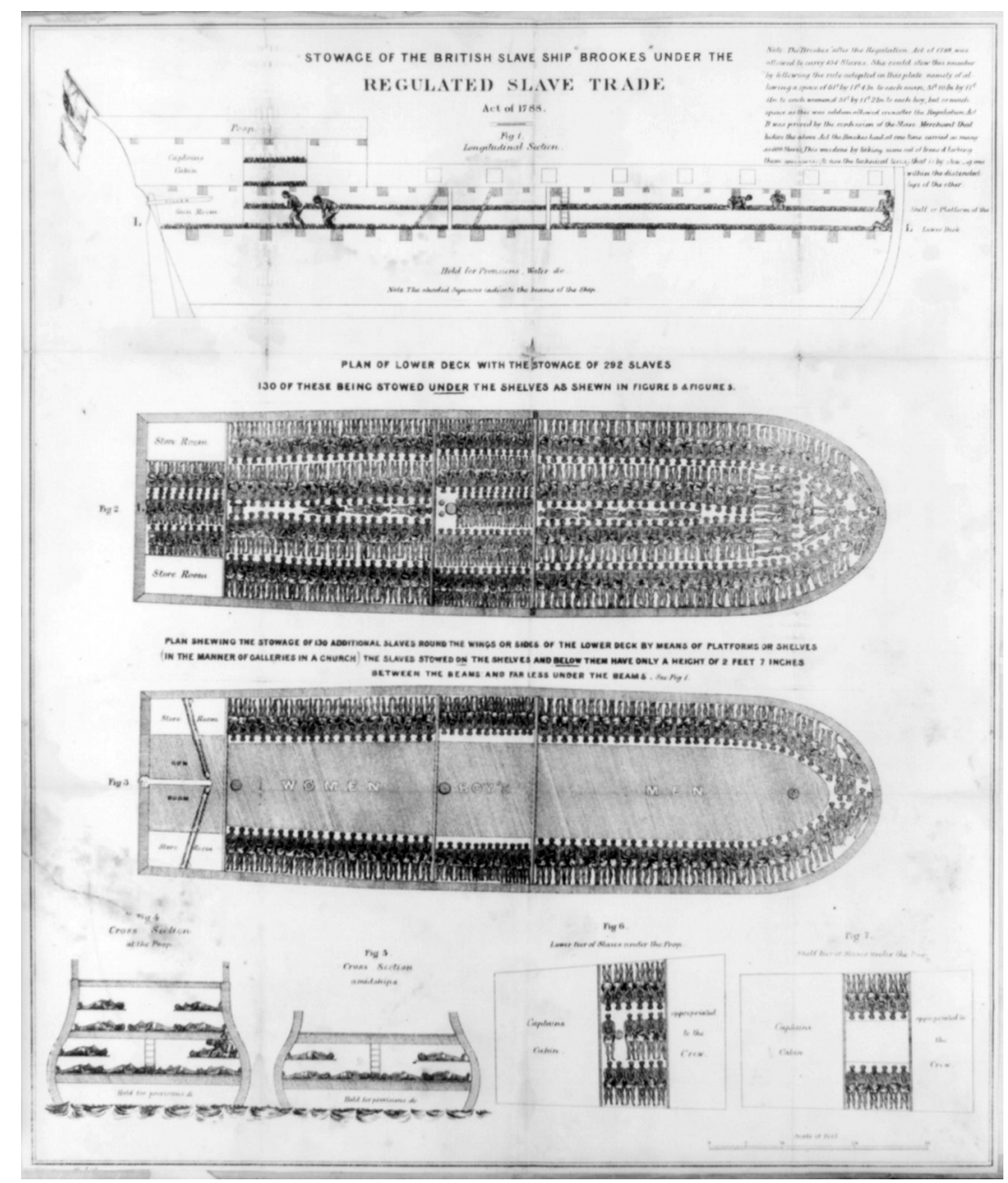

Figure 3: Stowage of the British slave ship Brookes under the Regulated Slave Trade Act of 1788, 1790. Image courtesy Library of Congress.

made evident to others. Such demonstrations may not always convince, and rarely succeed in generating the kinds of responses to what is being shown that make the evidence go away, if it's unjust, or secure it, if it's a claim. (The enslaved people of the British Empire waited until 1838 for legal emancipation.) Yet, in a variety of different contexts, across a range of media, the discourse of human rights seems to turn fundamentally on this question of evidence - its discovery or production, its presentation, and its reception. However, despite our common-sense notion of evidence as proof, the field is quite unstable.

Here is a proposition that seems, strangely, to be at once empirically trivial but also philosophically risky: we are not self-evidently human. Arguing for one's rights, or against their violation, is ultimately reducible to claiming that one belongs to the human community, that one's status is human. But that argument needs to be made; it does not go without saying. The status of being human appears to be 
rather uncertain, unsecured and subject to regular challenge and contest. It is not guaranteed by anything but other humans, and we are not good at guarantees. ${ }^{25}$

Evidence of this abounds in the world today. So many people are routinely not treated as we might expect them to be - they are tortured, trafficked, enslaved, targeted, disappeared, murdered, censored, exploited, and discriminated against. They seem not to count as human beings, not to qualify for the protections that ought to pertain to them. They are, in effect, not recognised as human, or have somehow had that status revoked. We see and hear of this all the time: human beings are not (treated as) humans.

In other words, and this is why my argument can be seen as philosophically risky, the category of human is ungrounded - hence philosophers' repeated efforts to specify or deny the 'foundations' of human rights. But perhaps these efforts are both impossible and unnecessary: human rights discourse is expressive, paradoxically, of the idea that membership in the human community is not something given in advance. There is a (quasi-)fundamental openness or instability in the concept of humanity, even if we all too often treat the violation or non-recognition of human status as something of the order of a mistake, a confusion, an accident; that is, something amenable to technical correction, an enlightening response, or an enforcement action. The problem goes much deeper than this - all the way down, in fact - and this groundlessness is constitutive of the concept. Moreover, this is not a critique, at least not in the ordinary sense of an argument that demands a better, more secure, concept. The predicament offers us a challenge and an opportunity.

Here is how Hannah Arendt posed this problem in her chapter on human rights and the nation-state in The Origins of Totalitarianism:

Man of the twentieth century has become just as emancipated from nature as eighteenth-century man was from history. History and nature have become equally alien to us, namely, in the sense that the essence of man can no longer be comprehended in terms of either category. On the other hand, humanity, which for the eighteenth century, in Kantian terminology, was no more than a regulative idea, has today become an inescapable fact. This new situation, in which 'humanity' has in effect assumed the role formerly ascribed to nature and history, would mean in this context that the right to have rights, or the right of every individual to belong to humanity, should be guaranteed by humanity itself. It is by no means certain whether this is possible. ${ }^{26}$

The key word here is 'guarantee', and Arendt's polite understatement of the impossibility of any such guarantee is one of the few concessions to human rights

25 I have addressed this further in 'Or Are We Human Beings?' in N. Axel, B. Colomina, N. Hirsch, A. Vidokle, and M. Wigley (eds), Superhumanity: Design of the Self (Minneapolis: e-flux architecture, Graham Foundation, University of Minnesota Press, 2018), 427-435.

26 H. Arendt, The Origins of Totalitarianism (New York: Harcourt Brace Jovanovich, 1951), 298. 
orthodoxy in her otherwise corrosively critical chapter. Membership of this openended community, then, is something negotiated, interpreted and demanded; nothing guarantees it a priori. Given the non-self-evidence of human status, a lot of other evidence is required.

\section{Non-self-evidence}

Evidence, in English, is a matter of appearance, of sight, of what manifests itself before the eye or in the realm of visibility. What is evident is what appears, what comes into the light, what comes into sight. The Latin root is ex-videre. To be evident is to be obvious, clear, visible. This does not have to happen naturally - evidence here is what enters, or is admitted into, a specific domain of visibility - but it is nevertheless only that which is presented to the senses, that which can be seen or heard.

Courts in the United States (and perhaps in other states as well) take this definition rather literally, even materially, which is to say minimally. Evidence means neither truth, nor proof; it implies nothing incontrovertible. It simply is what is there, not in the world but in the legal forum; it is whatever has entered into the specific time and place of juridical appearance, and on which a decision can be based. It is that which appears before a judge or a jury for their interpretation, the material for their decision about what the facts of a given case are.

In the penultimate moment of an American criminal trial, the judge usually instructs the jury about their role, and in particular about the material on which they are to base their verdict. The judge reminds the jury that their responsibility is simply to determine the facts in the case, not to interpret the law: the law is a formal grid which determines whether what happened constituted a crime. The jury decides what happened, they 'try the facts'; they answer the question: what took place? And they do this by assessing the evidence. In a typical set of instructions to a jury on the question of evidence, the judge says:

\subsection{Duty of Jury}

It is your duty to find from the evidence what the facts are. You will then apply the law, as I give it to you, to those facts. You must follow my instructions on the law, even if you thought the law was different or should be different.

Do not allow sympathy or prejudice to influence you. The law demands of you a just verdict, unaffected by anything except the evidence, your common sense, and the law as I give it to you.

\subsection{Evidence; Limitations}

I have mentioned the word 'evidence.' The 'evidence' in this case consists of the testimony of witnesses [the documents and other things received as exhibits] [the facts that have been stipulated - that is, formally agreed to by the parties] [the facts that have been judicially noticed - this is, facts which I say you may, but are not required to, accept as true, even without evidence]. You may 
use reason and common sense to draw deductions or conclusions from facts which have been established by the evidence in the case. ${ }^{27}$

This understanding of the word is quite simple, but this simplicity does introduce a complication: evidence is defined as information presented in testimony or in documents that is used to persuade the fact finder (judge or jury) to decide the case for one side or the other'. ${ }^{28}$

Evidence is what is presented and used to persuade. It does not mean what is true. In fact, it is precisely not that. It is not the matter of fact. Evidence does not convict, nor does it decide, nor does it settle or conclude or determine. It is that upon which a decision can be rendered about what the facts in a case are. A judge or a jury decides, or finds, or tries, those facts, in response to the evidence.

In other words, once again, evidence is precisely that which is not self-evident. It becomes evident only in the ears and eyes of others. It is not an answer, but a question: it asks for a decision, for a reading or an interpretation; it asks to be told what it says. To say that something is a 'question of evidence' is to speak redundantly: evidence is always a question.

To that question, two different sorts of responses can be given. There is the speech of judgment - the decision about what happened and what we conclude the evidence tells us. In a trial, this almost always happens. But a decision is not the only thing called for. If evidence is what is used to persuade, then we also need to attend to the acts and arts of persuasion, which is to say, to the rhetorical operations through which what is presented in evidence is presented to those who decide. This attention is another, equally important, form of response.

\section{Rewinding the movie}

In Ed Vulliamy's remarkable account of migration, maquiladoras, and the drug wars along the US-Mexico border, Amexica, we meet some of these interpretive/ rhetorical operations, as personified by a dedicated and dissident forensic pathologist named Dr Hiram Muñoz, who studies the bodies left behind in Tijuana's epidemic of narco-violence. ${ }^{29}$

The bodies come to him disfigured in a variety of horrible ways - Vulliamy offers a vivid catalogue of incisions, punctures, and removals - and Muñoz understands his task to be one of treating those marks as inscriptions, and decoding them. The bodies and skeletons that arrive for examination bear the traces of a range of life

27 'Final Instructions for Use in Every Trial (Boilerplate)', in Manual of Model Criminal Jury Instructions for the District Courts of the Eighth Circuit, (prepared by the Judicial Committee on Model Jury Instructions for the Eighth Circuit, 2017 Edition) 69-70, http://www.juryinstructions.ca8.uscourts.gov/Criminal-Jury-Instructions-2017.pdf (accessed December 2018). A footnote explains: 'The bracketed material should be given only if there has been documentary or exhibit evidence, stipulated evidence or judicially noticed evidence'

28 From the definition of the term 'evidence' in the 'Legal Terms Glossary' published by the Office of the United States Attorneys in Justice 101, http://www.justice.gov/usao/justice101/glossary.html (accessed December 2018).

29 E. Vulliamy, Amexica: War Along the Borderline, revised edition (New York: Farrar, Straus and Giroux/ Picador, 2011). For a graphically illustrated account of the violence, see Fugitive Reporters of Blog del Narco, Dying for the Truth: Undercover Inside the Mexican Drug War (Port Townsend, WA: Feral House, 2012). 
histories, but that is not his primary concern. The manner of death, and its symbolic language of mutilation, is his text. Vulliamy cites Muñoz's explanation of how he reads the codes:

Each different mutilation leaves a clear message. They have become a kind of folk tradition. If the tongue is cut out, it means they talked too much - a snitch, or chupro. A man who squealed on the clan has his finger cut off and maybe put in his mouth. This is logical, a traitor is known as a dedo - a finger ... Severed arms could mean that you stole from your consignment, severed legs that you tried to walk away from the cartel. Decapitation is another thing altogether: it is simply a statement of power, a warning to all, like public executions of old. The difference is that in normal times, the dead were 'disappeared' or dumped in the desert. Now they are executed and displayed for all to see, so that it becomes a war against the people. ${ }^{30}$

Having learned to translate this basic language, Muñoz admits to a particular interest in the incisions themselves, not the parts present or absent, but the traces of the surgery, for lack of a better word, performed by the medical students working with the cartels.

They are the ones trying to speak to us. I look at a cut-off toe. How was it done? Was it done well? Was it done from the left or the right? If it was done well, exactly between the bones, the person is more dangerous ... If it's just hacked off, we're dealing with a mana, a street thug. You need to cut it properly if you are going to send it to the victim's family, or the police. ${ }^{31}$

Muñoz protests to Vulliamy that his exhaustive labours rarely result in justice. 'The authorities don't look at any of this socially or forensically ... no one takes any notice. The narcos give us signs, they leave unique marks, like fingerprints, only the authorities do not heed them.'32 Nevertheless, he says, 'my job is to interrogate the corpse, to ask it questions. Because the dead cannot speak, I have to find ways of getting them to tell me what happened. ${ }^{33}$ Later, Vulliamy writes, Muñoz defines his work as

spending my life trying to scientifically interrogate people who cannot talk, who have suffered terrible pain but now feel nothing. They can communicate silently through the terrible things that have been done to them. I have to look for a cause, not a result. I have to rewind the movie, work out what was done, and why. ${ }^{34}$ 


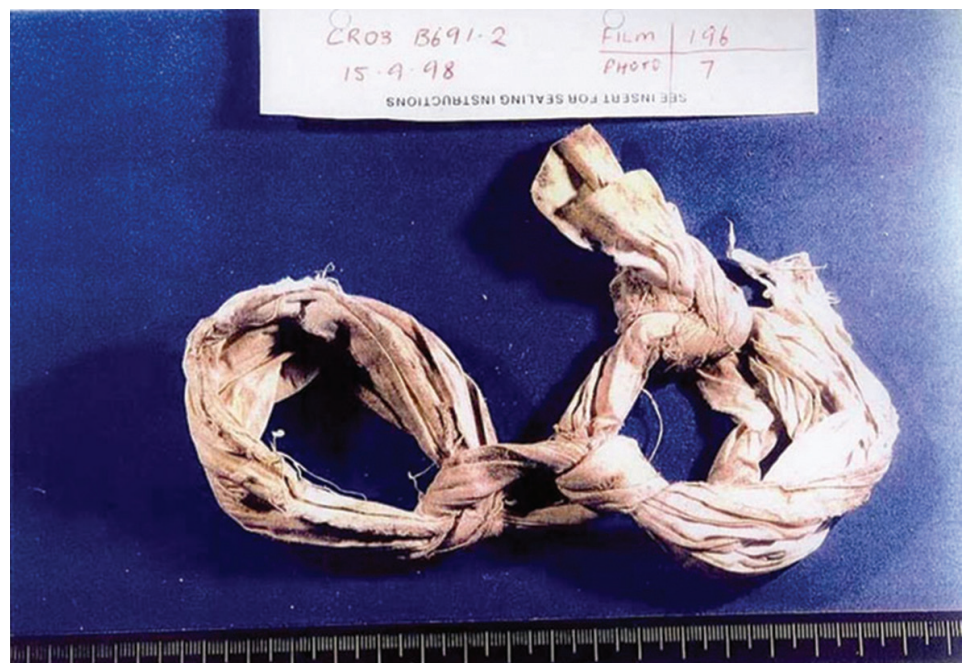

Figure 4: Ligature used to bind a victim's hands, unearthed during an exhumation in Srebrenica, Bosnia and Herzegovina. Photograph courtesy of the International Criminal Tribunal for the former Yugoslavia / Mechanism for International Criminal Tribunals.

Rewinding the movie is not just one metaphor among others. The bodies Muñoz examines, whether as bones or as flesh, bear the temporally dense and layered traces of the violence inflicted on them. Life-stories - 'osteobiographies', as Snow called them - are embedded in bones: not just the obvious markers of age, weight, height, gender, handedness, and so on, but histories of labour (jobs that involve walking look different in the bones than jobs that require sitting at a desk), nutrition, geography, health, and so on. Life stories, and death stories: how many bullets, what sort of bullets, from what weapon, at what range, at what angle? Were the hands bound, the eyes blindfolded? And so on. To all these questions, a skeleton can offer answers. Likewise, the flesh appears differently depending on what has been done to it. Muñoz is a very close reader of these imprints. But he is not only a reader, a listener or a watcher. $\mathrm{He}$ must also retell these stories - replay or narrate the film that no one else sees, give words to the silent communication of the corpses.

Part ventriloquist, part archaeologist, Muñoz lends words to the dead, showing what remains of them and offering an account of what they cannot say. He is a specialist in the art of prosopopoeia, a giver - or an imposer - of voice and of face. 'Because the dead cannot speak, I have to find ways of getting them to tell me what happened.' Once rewound, the film exhibits its imprints, starting with what is left behind, with what cannot be undone. Muñoz can nevertheless try to reverse time narratively and allow the story, if not the person, to return. But if the corpse tells what happened, it does so in a borrowed language, in words not its own. Its silent communication is transmitted through traces of things that happened, which is to say, through things alone. Someone else has to get those things to talk.

Communication, as Derrida pointed out long ago, doesn't only mean communication of a meaning. Muñoz tends to look for meanings, for messages in the traditional 
sense: this one was a snitch, that one trespassed, this other one stole. Because he fears them, he privileges the work of the professionals, the expert emitters of distinctive - even eloquent - semiosis. But as another of Vulliamy's sources, an anthropologist named Cecilia Ballí, points out, while 'specific types of violence exerted on the body can serve as a form of communication', this is not to say 'that violence always means something. ${ }^{35}$ Muñoz is equally aware that not all communications are significant, that not all messages transmit a meaning. Some simply, or not so simply, communicate a force, performing and announcing the existence of the speaker, or exemplifying the possibility of violence. ${ }^{36}$

\section{Automated evidence}

The medical students are craftspeople, of a sort, but sometimes evidence is produced automatically. In a sense, that is what forensic anthropologists typically confront as they decipher osteobiographies, at least in part: life has left its traces, unauthored and unintended, in and on the bones that remain.

Machines can also generate forensic material automatically. One of the great virtues of Vulliamy's story of drug violence in contemporary Mexico is that it's not only about drug violence, but also about the North American Free Trade Agreement (NAFTA), duty-free factories, US border security, the disappearance and murder of young women in Ciudad Juárez, smugglers and the traffic in migrants. And of these migrants, or some of them, astonishing automatically produced evidence exists.

On more than one occasion, backscatter X-ray scanners installed at US customs posts on the border with Mexico, and at checkpoints throughout much of Mexico itself, have generated images that send us back to the Brookes, showing traces of the contemporary trade in people, transported in conditions that rival those of centuries ago. As the New York Times reported in May 2011,

When police ran X-ray scanners over two cargo trucks at a checkpoint in southeastern Mexico on Tuesday, they made a surprising discovery: Inside the trailer were the ghostly shadows of 513 migrants - some suffering from dehydration - packed together in near-suffocating conditions. The police released an image of the harrowing scan, which shows how migrants sat in tight bundles or stood clutching cargo straps for hours of clandestine travel from beyond Mexico's border with Guatemala. ${ }^{37}$ Get Any Worse?' in J. Champlin (ed.) Terror and the Roots of Poetics, (New York: Atropos Press, 2013), 92-109.

37 J. D. Goodman, 'X-Ray Scan Reveals 513 Migrants in 2 Trucks', The Lede, New York Times online, 18 May 2011, https:// thelede.blogs.nytimes.com/2011/05/18/x-ray-scan-reveals-513-mexican-migrants-in-2-trucks/. See also Associated Press, '513 US-Bound Migrants Are Found on 2 Trucks in Mexico', New York Times, 17 May 2011. https://www.nytimes.com/2011/05/18/ world/americas/18mexico.html; S. Seijas, "Human Smuggling Exposed by Truck X-Ray', CBS News World Watch, 18 May 2011, http://www.cbsnews.com/news/human-smuggling-exposed-by-truck-x-ray/ (all accessed December 2018). 


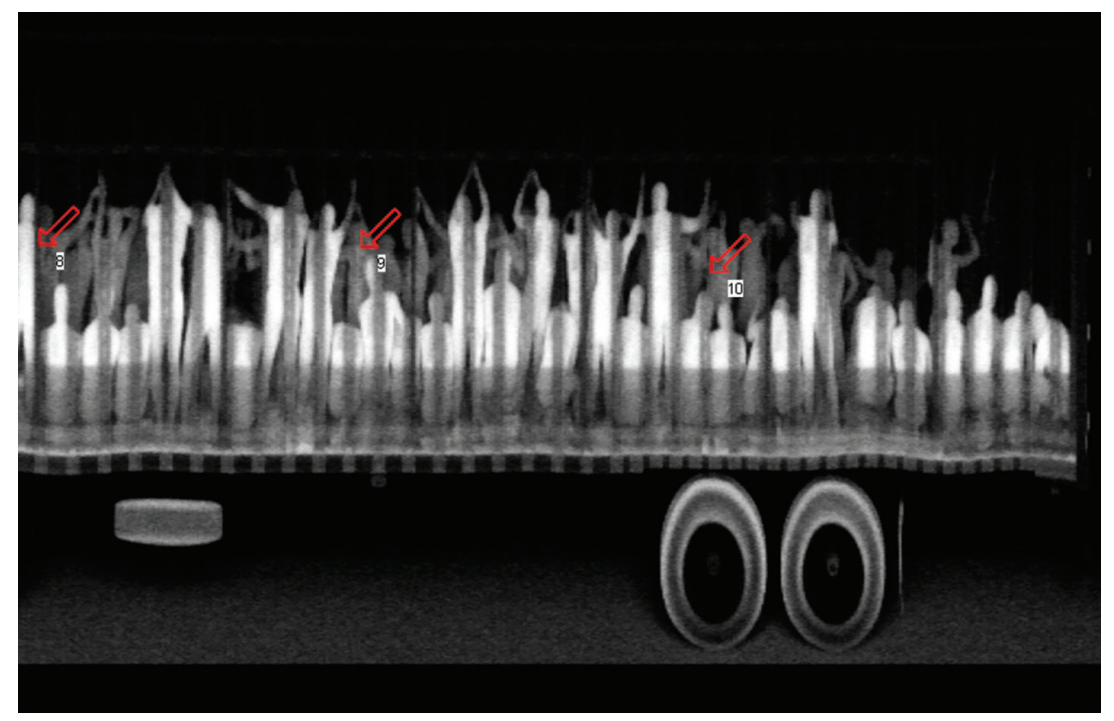

Figure 5: This X-ray image, from a handout distributed by the Chiapas State Attorney General's Office, was captured at a checkpoint near Tuxtla Gutierrez, in Mexico's southern Chiapas state, on Tuesday 17 May 2011, when over 500 migrants from Latin America and Asia were found inside two trailer trucks heading to the US. The red arrows are distance markers.

Long after the formal abolition of slavery, a profitable trade in people persists (at US $\$ 7,000$ per person, this 'cargo' of migrants from Latin America and Asia was worth more than $\$ 3.5$ million to the smugglers). What has changed, however, is that the images from Chiapas needed almost no human intervention to appear before us: no gathering of statistics, no measurements of the hold, no testimonies about cargo and conditions, no drawing and redrawing of the diagram. A machine, probably fitted with analytic algorithms that detect anomalies, produced the image and noticed the people - there, where people were not supposed to be.

In the 'ghostly' images, something like another voice from the grave was registered, and although the migrants did not reach their destination, and the traffic in people has not stopped, the image that captured that cry may well have saved their lives. Many others did not share that fate. ${ }^{38}$ Today, similar machines everywhere are tracking, counting, recording and monitoring data, images, and sounds, generating an uncountable quantity of evidence of all sorts of things. Often that evidence remains secret, or remains in the hands of commercial enterprises or governmental authorities, but sometimes it becomes public or can be acquired - or even commissioned - by citizens, activists, and NGOs.

Evidence of this sort has become a significant resource for another kind of human rights forensics. Although the Chiapas images, and most others like them, are

38 The graves of others who did not survive the crossing were not far off. CBS producer Susana Seijas reported that, in the weeks prior to this event, came 'the discovery of mass graves in San Fernando, Tamaulipas (just 90 km from Brownsville, Texas) where authorities found more than 183 decomposing bodies, many of whom were suspected migrants. There was a further discovery of 218 bodies in shallow graves in Durango state'. Seijas, CBS News World Watch, 18 May 2011. 


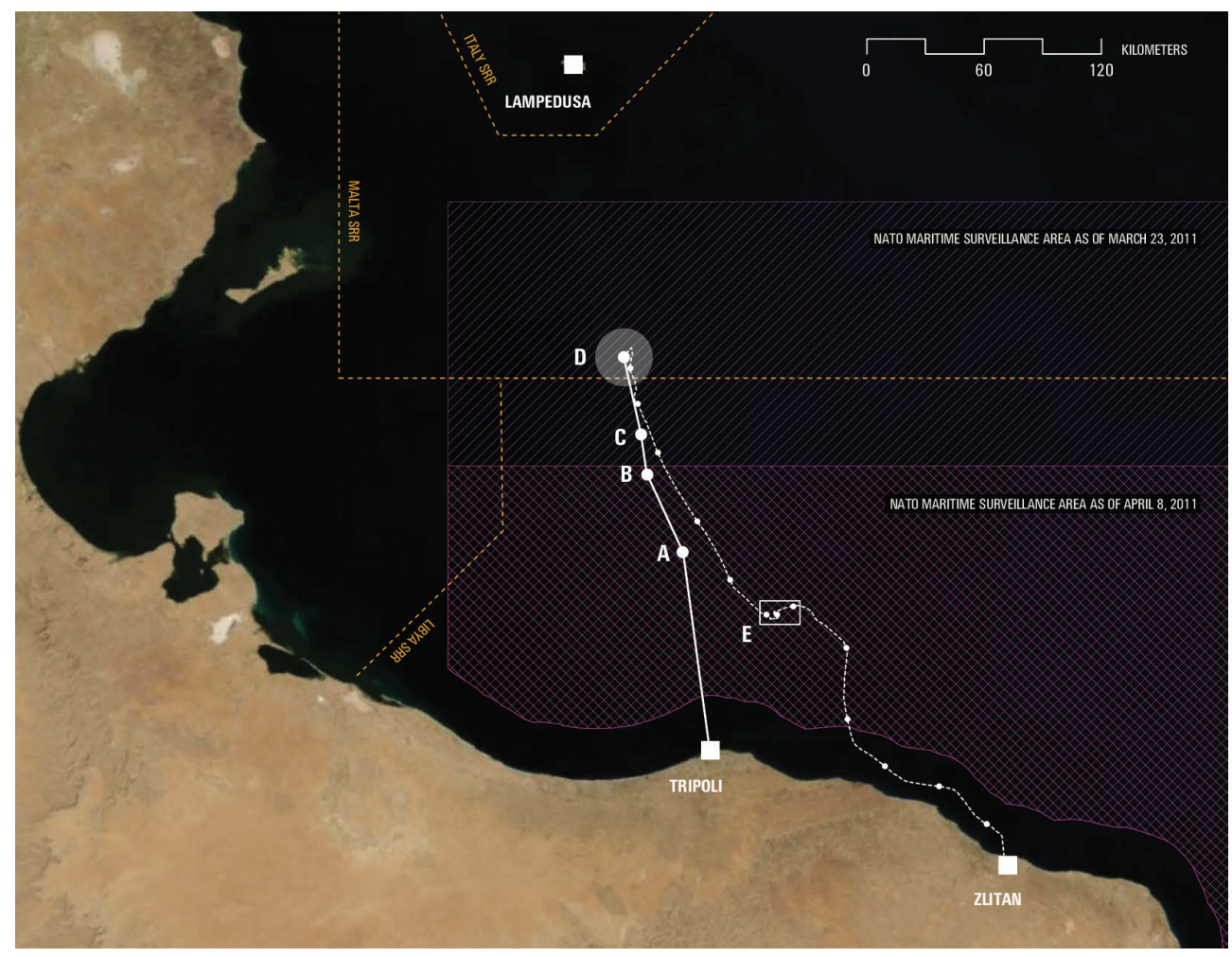

Figure 6: Map showing the voyage of the 'left-to-die boat'. On 27 March 2011, the boat left Tripoli with 72 migrants on board. On 10 April, the boat landed back in Libya; 11 migrants were still alive, two died shortly thereafter. Working 'against the grain' with surveillance technologies, the Forensic Oceanography project was able to reconstruct precisely how the voyage unfolded, revealing how different actors operating in the central Mediterranean Sea used their complex and overlapping jurisdictions to evade responsibility for rescuing people in distress. The letters A to E on the map mark the known and estimated locations of the boat based on GPS data from its satellite phone and encounters with naval vessels and aircraft. Map created by Forensic Oceanography, and used with permission.

produced by states or interstate agencies for the purpose of intercepting and stopping migration, their political force is not limited to that enforcement operation, as the analogy with the Brookes images suggests. Sometimes the repurposing of surveillance imagery becomes part of an activist, oppositional project, as for instance was the case when another migrant ship, the so-called 'left-to-die boat', set out from Tripoli in March 2011 bound for southern Europe.

In the midst of NATO's air and sea operation against the Libyan regime, the boat lost power and drifted. It was repeatedly encountered and not rescued by a variety of warships and aircraft, ultimately landing back on the Libyan coast 14 days after it set out. Of the 72 people on board, only nine survived. The sea is said to leave no traces. But the course of the ship has since been reconstructed. This was done using GPS tracking information from a satellite phone on the boat, automated wind and oceancurrent sensor data, tracking data from commercial vessels in the area, military 
records and surveillance images, and Synthetic Aperture Radar and high-resolution satellite images, as well as the testimony of the survivors which prompted the research in the first place. Discovering and making use of this trove of information, much of it automatically generated by the technologies of the very maritime border regime that is responsible for so many deaths at sea, has characterised the work of the Forensic Oceanography team that did this exemplary counter-forensic research. ${ }^{39}$

\section{Staging the truth}

But beyond this militant transformation of high-tech and often state-sponsored evidence into material for human rights claims, Forensic Oceanography and other contemporary counter-forensic projects testify to something else, apparently more old-fashioned. They are committed to what my colleague Oraib Toukan once called 'staging the truth'.

In February 2011, Eyal Weizman and I brought together a number of students and colleagues for a seminar at Bard College with human rights investigators, including Stefan Schmitt, director of the International Forensics Program at Physicians for Human Rights and former leader of the Guatemalan Forensic Anthropology Foundation. As Schmitt explained his protocols for exhuming mass graves, and just as importantly, for photographing that process, he referred regularly to the importance of producing evidence that requires as little explanation in court as possible. Once again, we found ourselves confronting the trope with which I began. 'If the thing can talk for itself', he said, 'then you don't have to say anything or make a judgment - everybody else in the room will come to the same conclusion.' And Schmitt affirmed the approach to evidence underlying the figure of speech. Evidence, he reminded us, is simply 'that which is legally submitted to a competent tribunal as a means of ascertaining the truth of any alleged matter of fact under investigation before it ... It becomes evidence as soon as a judge says 'this is evidence and you can submit it to my court' —and that determines how I collect it.' The bones need to be exhumed, yes, but the scenes need to be prepared and documented carefully, following rules and protocols that are produced in order to generate the maximum transparency: 'You never know what this is going to be important for ten years from now.

To this Toukan asked, or rather proposed, 'So you're, effectively, staging the truth.' 'Staging', of course, when said in a certain tone, could constitute a serious indictment of the investigative process, as when we charge a photographer with having staged a picture. But Schmitt understood the proposition differently, as a translation of just what he had been saying. 'Yes,' he answered immediately. 'It sounds horrible the way you're saying it, I mean, "you're staging the truth", but yes, you're preparing, that's exactly what it is. ${ }^{30}$ The scene, the stage, needs to be

39 See the extensive documentation of the 'left-to-die boat', and others, by the Forensic Oceanography team at https://www.forensicarchitecture.org/case/left-die-boat/ (accessed December 2018).

40 Stefan Schmitt made these remarks at a Forensics Workshop hosted by Bard College in Annandale-on-Hudson, NY in February 2011; a video of Schmitt's presentation, Stefan Schmitt: Bard College Part 1 is available at https://vimeo.com/41673058 and the remarks quoted can be found at 14:30', 30:00' and 1:05:00'. 
prepared, made camera-ready, as it were, so that the truth of the matter has a chance of appearing later, maybe much later, in forums the existence of which we do not yet even suspect. And a great deal of work goes into preparing that stage.

This non-naive commitment to a notion of the truth might seem surprising, but it informs much contemporary counter-forensics. A rich notion of forensics implies that things happen, traces are left behind, and disputes ensue about the meaning of those traces, about what it is exactly that they testify to. Because there is an imprint, there is the possibility for interpretation and hence for disagreement - this conflictual battleground of readings does not take place because there is no truth, but rather because there is.

\section{Fragments and ghosts}

In the final scene of Witnesses from the Grave, Eric Stover and Christopher Joyce's account of the career of Clyde Snow and the birth of the Argentine forensic team, Snow and three members of the team are taking a break from exhuming a mass grave. ${ }^{41}$

It has been raining and they cannot dig, so they have retreated to the countryside. They sit by the edge of a stream. Snow reads a book, and his 'companions watch leaves and small branches collect in an eddy near his feet'. They exchange stories about their dreams, a pastime which, the authors tell us, is 'something they do when the mood strikes'. These are not their hopes and dreams for the future, but rather what they have been dreaming at night. And they dream about bones: 'Luis [Fondebrider] describes his latest. He is sitting in a cafe in the Florida district with a beautiful woman beside him. He leans forward to kiss her. But just before their lips meet, she turns into a skeleton.'

Most of the dreams recounted by the newly-trained forensic team share this strange temporal dynamic. Time accelerates, the passage through life goes too quickly, disappears in an instant, and the face is replaced by a skull. Even when we are alive, we are just waiting to be revealed as the skeletons we inevitably are. The young Argentines who have been spending most of their days in the dirt with bones seem to have developed a strong sense of our collective destiny.

But perhaps this story should be told in reverse, the movie rewound: the dreamer here knows only the skeleton, and reanimates it - that is his work, in a sense - just long enough to imagine a more intimate relation to it. The bodies they are exhuming, after all, are those of strangers, people with whom the members of the team have no connection other than a sense that they deserve some sort of justice or accounting. So the reanimation that is this forensic work lasts long enough to make it clear that if the bones do come to life, in some sense, if they become active in the present, they nevertheless do not come back to their former lives - they remain bones, even as they move, kiss, dance, have stories to tell. Life is restored, or granted, but to the bones as such, not to the bodies they once structured. They look like skeletons, but they act

41 Joyce and Stover, Witnesses from the Grave, 304-305. 
like ghosts, spectral or hallucinatory remnants of a past that cannot be undone or restored but which can still have effects. The work of the team fosters this hallucination, in the best sense; perhaps that is why they like to talk about their dreams.

Snow, who has been reading, does not contribute a dream to the conversations but simply tells a joke, and as they laugh, the book ends this way:

The sun, as if cued by their laughter, breaks through the cloudy El Tigre sky. Shivering, Pato [Patricia Bernardi] pulls her shawl over her shoulders. 'How can the sun make you cold?' Luis asks, wrapping his arm around her. 'Because it means we'll be digging again'. Snow looks up from his page. With a willow branch, he leans over the swirling knot of debris near his feet and pushes it free. They watch as it slowly floats downstream, out of sight, toward the sea. ${ }^{42}$

The allegory is clear enough. The younger members of the new team, driven by a passion to clarify the past and see some sort of justice done, live an oscillation of de- and re-animation. They dream, awake and in sleep, of the possibility that the dead might speak, and of the certainty that our animated, speaking existence here today is only a temporary condition. They are living in the graves, still digging even when they sleep. Even the sun only promises a renewed encounter with this task; indeed, the emergence of the sun means that the bones will once again be revealed and start speaking. The narrative endorses their determination to make the past speak to the present, their pursuit of another kind of evidence that will join the eyewitness testimony and the documents in future trials.

Snow shares this knowledge - he has taught it to them - and he has seen and done enough to know also that a slightly different gesture is also required, another sort of relation to what comes to us from the past, to the pieces and parts of the past that accumulate in knots of debris over time. He pushes it free, and lets it float out of sight. Rather than returning, it disappears.

She thinks of digging again, he liberates the flotsam. Is this the same project? The narrative, although it gives the last move to Snow, does not, I think, choose between them. The rain is the enemy; that much is clear. But the sun, at once the condition of possibility of their work and the emblem of its activist enlightenment sensibility, the figurative agent of the voice of the dead ('almost as soon as the sun touched them, the bones started telling their stories') sheds an ambivalent light. It allows the dead to appear, maybe to reappear to the living, but it confirms them as dead and bleaches away any fantasy of redemption or nostalgia.

'How can the sun make you cold?' is not a rhetorical question, or a poetic lament. It is a melancholic testament to the ineradicable fact of ruin as a forensic condition, and it helps us understand what is most important about evidence and human rights. 
Forensics, which is, among other things, constituted by the direct encounter with the stubborn fact of the past - with the past as debris - sometimes forgets this fact. Sometimes, just as stubbornly as the thing resists, the researcher struggles to make it present, to bring it out of its decay and irrelevance, and allow it to belong to us, here and now, securely. This is registered in the triumphal narratives of forensic success, of truth and identity ascertained, of the bones that 'never lie and never forget', as Snow famously said. ${ }^{43}$

But the past cannot simply be made present, no matter how good the experts are at digging or interpreting. It can be made wholly present just as little as it can remain fully past. The confident stories of forensic certainty are an attempt to hide from this, to keep the remains settled in one place or the other: definitively anchored in a bygone past, and telling the truth in our present. The relics to which forensics respond are neither simply past nor present, in fact. In different ways, the stories told by the gravediggers on the riverbank testify to this. The sun makes them cold because it sends them back into the grave with bones that demand to be spoken of, with remains that want to have their say in another's voice, because although they are certainly dead they are just as certainly not gone. But the debris needs to be let loose as well as recovered; it does not belong to those who exhume it, and through whom it bears witness, but instead resists appropriation - as well as forgetting. Rather than being possessed, what is left to be found can come to possess its interpreters, to demand of them that they speak and tell what happened. The ones who go into the graves know, better than anyone else, that nothing guarantees that the past is past, nothing secures it in the present, nothing prevents it from coming back, and going back. They know that afterlives are always possible, and hence that there is always evidence to be found, stories to be told, struggles to be waged, claims to be made. 